\title{
STUDI LITERATUR PENCAMPURAN MATERIAL TANAH LEMPUNG DAN PASIR BATU DENGAN STEEL SLAG
}

\author{
Stefi Kurniawan ${ }^{1}$, Inda Sumarli ${ }^{2}$, dan Ali Iskandar ${ }^{3}$ \\ ${ }^{1}$ Program Studi Sarjana Teknik Sipil, Universitas Tarumanagara, Jl. Letjen S. Parman No.1 Jakarta \\ Stefi.325160014@stu.untar.ac.id \\ ${ }^{2}$ Program Studi Sarjana Teknik Sipil, Universitas Tarumanagara, Jl. Letjen S. Parman No.1 Jakarta \\ Indas@ft.untar.ac.id \\ ${ }^{3}$ Program Studi Sarjana Teknik Sipil, Universitas Tarumanagara, Jl. Letjen S. Parman No.1 Jakarta \\ aliiskandar@ft.untar.ac.id
}

\begin{abstract}
The use of steel slag has been widely used to increase soil strength. Steel slag is solid material from the process of refining molten iron in making steel which in the process uses furnace and using fuel from the air blown. The steel slag must be utilized cautiously because this material is categorized as B3 which is dangerous and toxic. The application that will be discussed in this research is "Literature Study of Mixing Clay and Sandstone with Steel Slag". This analysis will be conducted by comparison of the data from research findings. The data used are primary and secondary. For primary data, the mixing of steel slag material is fulfilled by sandstone while this material is mixed with clay for secondary data. The experimet carried out from the data obtained are the CBR test, optimum moisture content (OMC), spesific gravity, maximum dry density, and atterberg limit. The results of data comparison; in addition of certain steel slag consist of a maximum number increase of CBR value. In addition, the growth of steel slag content can also increase spesific gravity of soil, and reduce plasticity, liquid limit and moisture content.
\end{abstract}

Keywords: california bearing ratio $(C B R)$; steel slag; clay; sandstone

\begin{abstract}
ABSTRAK
Penggunaan limbah baja telah banyak digunakan untuk peningkatan kekuatan tanah. Limbah terak baja merupakan limbah padat dari proses pemurnian besi cair dalam pembuatan baja yang dalam prosesnya memakai tungku dapur dan menggunakan bahan bakar dari udara yang ditiupkan. Limbah baja ini harus dimanfaatkan sebaik-baiknya karena bahan ini termasuk kedalam limbah B3 yang Bahan Berbahaya dan Beracun. Pemanfaatan yang akan dibahas dalam penelitian ini adalah Studi Literatur Pencampuran Material Tanah Lempung dan Pasir batu dengan Steel Slag. Di dalam penelitian ini, dilakukan dengan perbandingan data-data dari hasil penelitian. Data-data yang digunakan adalah data primer dan sekunder. Untuk data primer, pencampuran material limbah baja dilakukan dengan pasir batu sedangkan untuk data sekunder material ini dicampurkan dengan tanah lempung. Pengujian yang dilakukan dari data-data yang didapat adalah pengujian CBR, kadar air optimum, berat jenis butir, berat jenis tanah, dan batas-batas atterberg. Hasil dari perbandingan beberapa data yang didapat, pada penambahan kadar limbah baja tertentu terdapat pertambahan nilai CBR paling maksimum. Selain itu, pertambahan kadar slag juga dapat meningkatkan berat jenis butir, dan mengurangi plastisitas, batas cair, dan kadar air.
\end{abstract}

Kata kunci: california bearing ratio (CBR); limbah baja; tanah lempung; pasir batu

\section{PENDAHULUAN}

Industri yang saat ini makin maju dalam perkembangannya adalah industri pengolahan pada baja. Limbah baja termasuk kedalam limbah B3 (Bahan Berbahaya dan Beracun) padat yang secara fisik menyerupai agregat kasar yang disebut steel slag. Sesuai dengan Peraturan Pemerintah Nomor 11 Tahun 2014 tentang Pengelolaan Limbah Bahan Berbahaya dan Beracun (B3) steel slag merupakan suatu bahan yang tidak berbahaya jika dimanfaatkan untuk konstruksi perkerasan jalan. Karena atas dasar pemikiran tersebut, maka perlu diadakan suatu percobaan untuk pemanfaatan limbah industri pengolahan baja dari awalnya material ini dapat merusak lingkungan, menjadi sesuatu yang dapat dimanfaatkan salah satunya pada pekerjaan prasarana transportasi yang dapat digunakan sebagai bahan campuran tanah untuk perkerasan jalan. Tujuan dari penelitian ini adalah memanfaatkan limbah 
yang diakibatkan oleh pembakaran baja dibidang konstruksi pada bagian perkerasan jalan, dan menentukan komposisi yang tepat untuk memanfaatkan limbah baja.

\section{Terak baja}

Terak baja merupakan limbah padat dari proses pemurnian besi cair dalam pembuatan baja. Menurut FHWA Nomor Publikasi: FHWA-RD-97-148, terak baja (slag) merupakan produk sampingan dari pembuatan baja, diproduksi selama pemisahan baja cair dari kotoran di tungku pembuatan baja. Terak dalam ASTM. C.989, "Standard spesification for ground granulated Blast-Furnace Slag for use in concrete and mortar (ASTM, 1995:494) adalah produk non-metal yang merupakan material berbentuk halus sampai balok-balok besar, granular hasil pembakaran yang kemudian didinginkan.

\section{Tanah}

Tanah dari pandangan ilmu Teknik Sipil merupakan himpunan mineral, bahan organik dan endapan-endapan yang relative lepas (loose) yang terletak di atas batu dasar (bedrock). Tanah juga didefinisikan sebagai akumulasi partikel mineral yang tidak mempunyai atau lemah ikatan partikelnya, yang terbentuk karena pelapukan dari batuan.

\section{Kadar air ( $\omega)$}

Kadar air suatu tanah adalah perbandingan antara berat air yang terkandung dalam tanah dengan berat kering tanah yang dinyatakan dalam persen. (ASTM D 2216-98). Kadar air dalam tanah dibutuhkan untuk menghitung parameter sifat-sifat tanah.

\section{California bearing ratio (CBR)}

Nilai CBR adalah presentae antara daya dukung tanah yang diteliti yang dibandingkan dengan daya dukung batu pecah standar pada nilai penetrasi yang sama ( 0.1 inch dan 0.2 inch), ketentuan angka tertinggi yang digunakan. Nilai CBR yang diukur dalam 2 kondisi, yaitu kondisi soaked (terendam) dan unsoaked (tidak terendam).

\section{Spesific gravity}

Sifat fisik tanah dapat ditentukan dengan mengetahui berat jenis tanahnya dengan cara menentukan berat jenis yang lolos saringan No. 200 menggunakan labu ukur. Menurut Standar Nasional Indonesia SNI 1964-2008, pengertian berat jenis butir tanah adalah perbandingan antara massa isi butir tanah dan massa isi air pada temperatur $4^{0} \mathrm{C}$.

\section{Analisa besar butir}

Grain Size adalah suatu usaha untuk menentukan distribusi butiran pasir dan butiran-butiran tanah yang lebih kecil dari butiran-butiran pasir yang lolos saringan no. 200 serta menentukan klasifikasi jenis tanah dan membandingkan persentase butiran-butiran pasir, lanau, dan lempung.

\section{Kompaksi}

Pengujian kompaksi ditujukan untuk mendapatkan kadar air optimum pada saat kepadatan maksimum (W optimum dan $\gamma \mathrm{d}$ maksimum).

\section{Kembang susut tanah (swelling)}

Kembang susut tanah merupakan peristiwa mengembangnya tanah yang disebabkan karena meresapnya air kedalam pori-pori tanah menggantikan udara akibat penambahan beban. Pengujian ini memiliki tujuan untuk mengetahui besar presentase pengembangan dan tekanan tanah pada saat kondisi sedang dibebani.

\section{Plastic limit/batas plastis (PL)}

Batas Plastis adalah keadaan dimana tanah saat memiliki kadar air terendah lalu tanah mulai berubah sifatnya menjadi plastis. Pengujian ini dilakukan dengan cara menggulung tanah sampai berdiameter 1/8 inch (3.2 mm) menjadi retak.

\section{Liquid limit/batas cair (LL)}

Batas cair adalah kondisi kadar air tanah dimana sifat tanah mulai berubah dari plastis menjadi cair. Pada kondisi ini tanah memiliki kuat geser yang rendah. Nilai batas cair adalah kadar air pada ketukan ke $25(\mathrm{~N}=25)$. 


\section{METODE PENELITIAN}

\section{Jenis penelitian}

Jenis penelitian yang akan digunakan adalah studi literatur. Penelitian yang akan dilakukan adalah membandingkan hasil-hasil penelitian pencampuran material slag dengan tanah dan pasir batu.

\section{Metode pengumpulan data}

Metode yang dilakukan dalam pengumpulan data ini adalah studi dokumen. Jenis data yang diambil dalam penelitian ini adalah data primer dan sekunder. Data primer merupakan data atau informasi yang diperoleh tidak secara langsung dari obyek penelitian yang belum dipublikasi terletak pada data 1. Data sekunder merupakan data atau informasi yang diperoleh secara tidak langsung dari obyek penelitian yang bersifat public terletak pada data 2 -10 .

\section{Pengolahan data}

Pengolahan data yang dilakukan pada penelitian ini adalah dengan menggabungkan beberapa data dari literatur yang ada lalu, data-data tersebut dibandingkan.

\section{HASIL DAN PEMBAHASAN}

\section{Analisis data}

Data primer yang digunakan dalam penelitian ini adalah data 1 sedangkan, nntuk data sekunder berada pada nomor 2-10 karakteristik datanya adalah:

1. Karakteristik slag pada data 1 adalah besar butirnya paling besar $19 \mathrm{~mm}$. Slag dicampurkan pada material sirtu dan semen. Semen yang digunakan hanya 4\% untuk presentase campuran slag $76 \%+$ sirtu $20 \%$. Sumber: Laporan Pengujian Laboratorium Electric Furnace Cilegon, Banten, 2017

2. Data sekunder 2 tanah yang digunakan adalah tanah lempung ekspansif (dengan IP $=54,4$ dan $\mathrm{LL}=$ $79,76 \%$ ). Presentase slag yang dicampurkan $0 \%, 5 \%, 10 \%$, 15\%, sampai dengan 20\%. Sumber data: Pengaruh Penambahan Limbah Baja (Slag) Pada Tanah Lempung di Daerah Babat Lamongan.

1. Tanah yang digunakan pada data 3 adalah tanah high plasticity clay and silt (dengan IP $=23,64 \%$ dan LL $=51,9 \%$ ). Slag yang digunakan dalam penelitian ini termasuk butir halus, dengan ukuran butiran paling besar 4,75 mm. Sumber data: Effect of By-Product Steel Slag on the Engineering Properties of Clay Soils.

2. Tanah yang digunakan pada data 4 adalah tanah lempung berbutir kasar dengan presentase kerikil $63 \%$, pasir $27 \%$ dan lanau 10\%. Termasuk kedalam tanah high plasticity (dengan IP $=22 \%$ dan LL $=51 \%$ ). Dan butiran slag yang digunakan juga termasuk butir kasar, yang terdiri dari $86 \%$ kerikil dan $14 \%$ pasir. Sumber data: Steel Slag Waste Material for the construction of Road.

3. Tanah yang digunakan pada data 5 adalah tanah lempung berbutir halus (paling besar 4,75 mm). Butiran slag yang digunakan pada penelitian ini adalah butir halus. Sumber data: Soil Stabilisation Using Ground Granulated Blast Furnace Slag.

4. Tanah yang digunakan pada data 6 adalah marine clay bertekstur butir halus dengan highly plastic (dengan IP $=37,78 \%$ dan $\mathrm{LL}=70,7 \%$ ). Slag yang digunakan pada data ini berbutir halus (paling besar 4,75 mm). Sumber data: A Laboratory Study on the Affect of Steel Slag for Improving the Properties of Marine Clay for Foundation Beds.

5. Tanah yang digunakan pada data 7 adalah high plasticity clay (dengan IP $=36 \%$ dan LL $=66 \%$ ). Dan slag yang digunakan pada penelitian ini adalah berbutir halus. Sumber data: Laboratory Study of Steel Slag Used in Stabilizing Expansive Soil.

6. Tanah yang digunakan pada data 8 adalah organic high plasticity soil (dengan IP $=40,12 \%$ dan LL $=$ 73,58\%). Slag yang digunakan halus (seperti semen). Sumber data: Studi Laboratorium Variasi Campuran Slag Baja dan Slag Feronikel Terhadap Penurunan Kadar Air, Peningkatan Nilai CBR, dan Kuat Tekan Tanah, Studi Kasus Jalan Tol Bocimi STA. 19+125, Bogor.

7. Tanah yang digunakan pada data 9 adalah black cotton soil high plasticity. Ukuran butir tanah melewati saringan ukuran 4,75 mm. Sumber data: Investigation on Percentage Addition of Sand, Red murrum and Steel slag for Strengthening the Subgrade Soil.

8. Tanah yang digunakan pada data 10 adalah tanah lempung (IP $=22,05 \%)$. Presentase butiran slag antara kerikil dan pasir adalah $1 \%$ dan 95\%, dan ukuran partikel halus adalah 4\%. Sumber data: Influence of Steel Slag and Fly Ash on Strength Properties of Clayey Soil: A Comparative Study. 


\section{Hasil analisis}

\section{Grafik pengaruh penambahan slag terhadap nilai california bearing ratio (CBR)}

Pada data 2 (gambar 1) saat campuran tanah dengan slag sebesar 5\%, 10\%, 15\%, dan 20\% nilai CBR bertambah sebesar 2,49\%, 4,787\%, 7,84\% hingga 12,18\%. Pada data 3 (gambar 2) dilakukan pencampuran slag dengan presentase $0 \%, 5 \%, 10 \%, 15 \%, 20 \%, 25 \%$, dan $30 \%$ adalah sebesar 2,8\%, 3,52\%, 4,13\%, 4,61\%, 4,97\%, 5,22\%, $5,34 \%$.

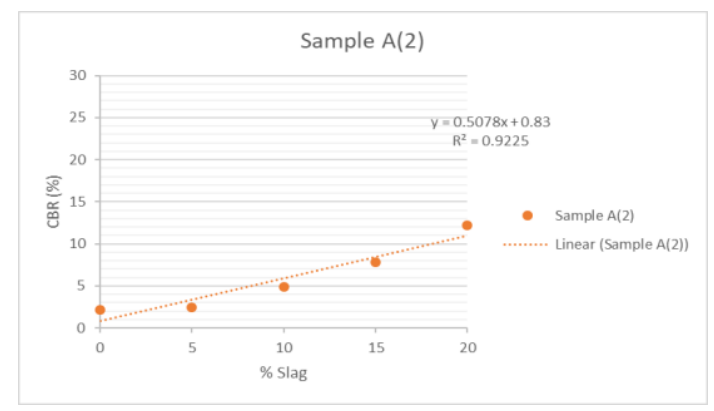

Gambar 1. Grafik penambahan nilai CBR sampel A data 2 (Sumber: Ardiyanti dan Andajani, 2014)

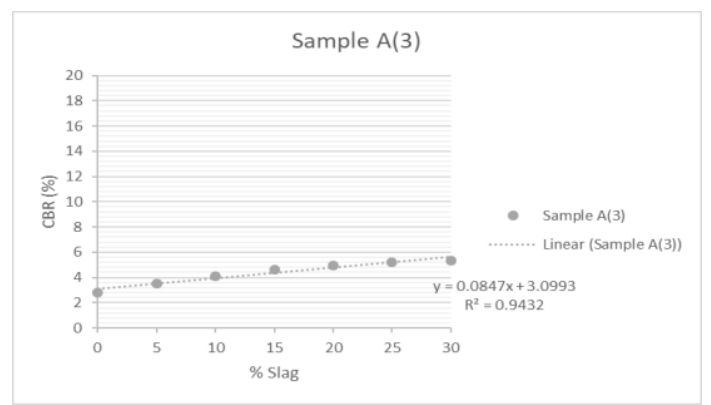

Gambar 2. Grafik penambahan nilai CBR sampel A data 3 (Sumber: Shalabi, dkk, 2016)

Nilai CBR tanah asli pada data 4 (gambar 3) adalah 22\%, akan meningkat dengan adanya penambahan slag sebesar 25\%, 50\%, 75\% nilai CBR nya menjadi 35\%, 60\%, dan 80\%. Pada data 5 (gambar 4), pencampuran tanah dengan slag sebanyak $0 \%, 5 \%, 10 \%, 15 \%, 20 \%$ dan 25\%. Nilai CBR akan meningkat mulai dari 2,84\%, 3,13\%, $3,44 \%, 3,77 \%, 4,06 \%$, hingga $4,41 \%$.

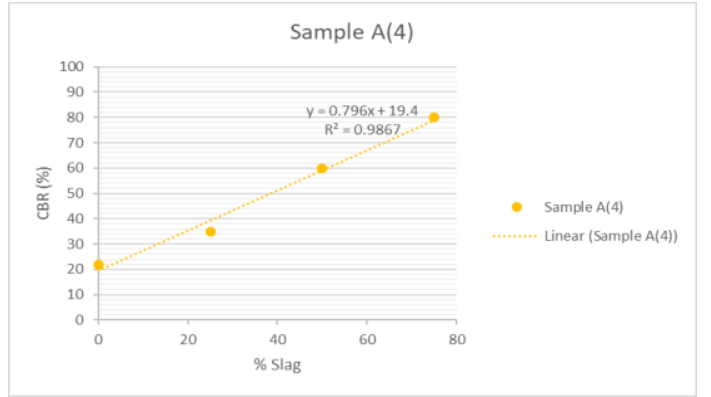

Gambar 3. Grafik penambahan nilai CBR sampel A data 4 (Sumber: Sinha, dkk, 2013)

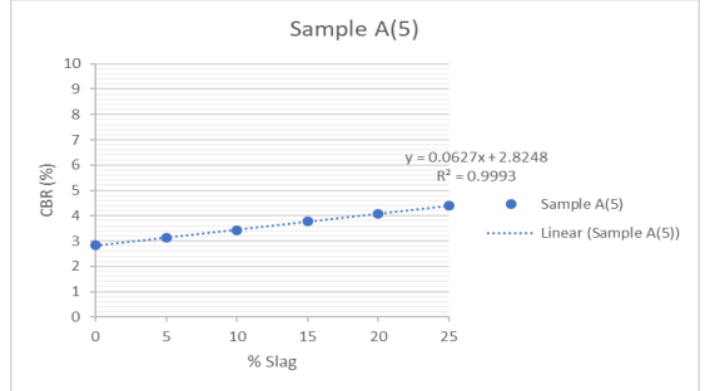

Gambar 4. Grafik penambahan nilai CBR sampel A data 5 (Sumber: Pathak, dkk, 2014)

Pada data 6 (gambar 5), saat pencampuran tanah dengan slag sebesar 0\% dan 10\% besarnya CBR bertambah mulai dari $1,345 \%$, lalu 9,436\%, dan untuk persentase $13 \%$ nilai CBR 14,435\%. Pada saat pencampuran tanah dengan slag sebesar $15 \%, 18 \%$, dan sampai $20 \%$ nilai CBR menjadi 5,46\%, 5\%, dan hingga 2,96\%. Nilai CBR pada tanah asli data 7 (gambar 6) adalah 2,4\% akan bertambah menjadi 3,5\% ketika penambahan slag sebesar 5\%, lalu saat $15 \%, 20 \%$ dan $25 \%$ nilai CBR bertambah menjadi 5,2\%, 6\%, 9,09\%, dan 6,8\%. 


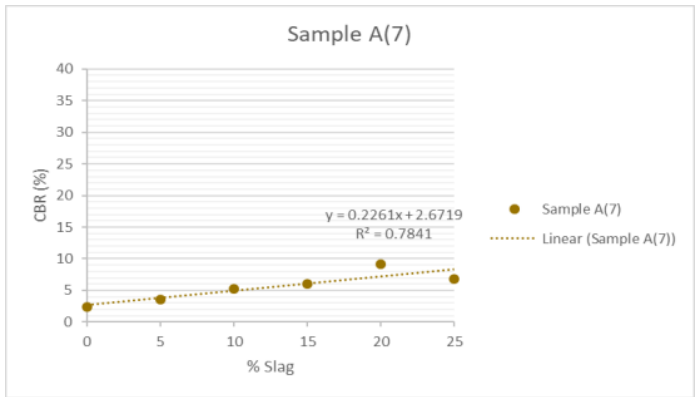

Gambar 5. Grafik penambahan nilai CBR sampel A data 6 (Sumber: D. Koteswara Rao, dkk, 2014)

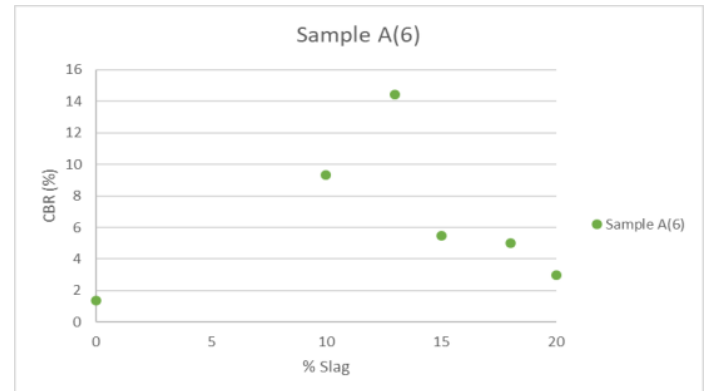

Pada data 8 (gambar 7), CBR tanah asli sebesar 2,11\%, lalu pada saat pencampuran slag dengan tanah sebesar 5\% nilai CBR naik menjadi 3,16\% dan pada saat pencampuran slag dengan tanah sebesar $10 \%$ nilai CBR menjadi 2,66\%. Pada data 9 (gambar 8), terjadi kenaikan nilai CBR pada tanah yaitu pada tanah asli nilai CBR sebesar $3,46 \%$, pada pencampuran tanah dengan slag sebesar $10 \%$ nilai CBR naik menjadi $4,52 \%$, lalu pada penambahan slag sebesar 20\%, 30\%, 40\% dan 50\% nilai CBR yang didapat adalah 5,78\%, 6,74\%, 7,55\%, dan 7,7\%.

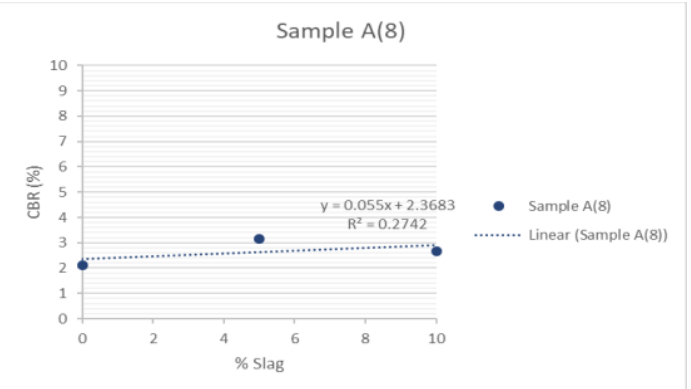

Gambar 7. Grafik penambahan nilai CBR sampel A data 8 (Sumber: Kurnaedi, 2019)

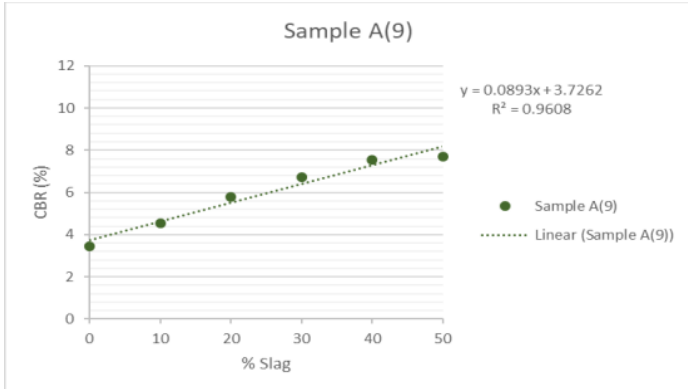

Gambar 8. Grafik penambahan nilai CBR sampel A data 9 (Sumber: Palve and Sharma, 2018)

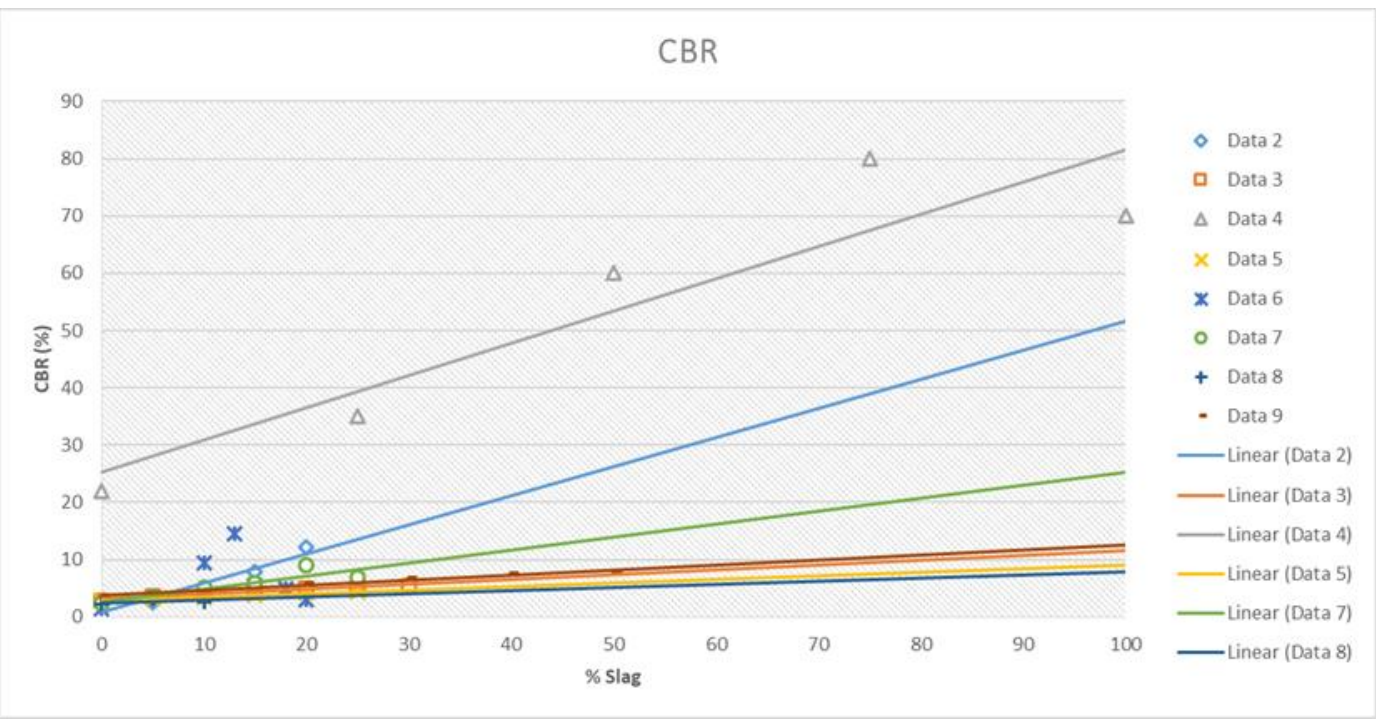

Gambar 9. Perbandingan kenaikan CBR pada tanah lempung dengan slag

Dari hasil perbandingan data yang dilakukan pada gambar 9, dapat diketahui dengan menambahkan slag pada tanah asli akan mengakibatkan naiknya nilai CBR tanah. Pada kadar persentase slag tertentu, terdapat pertambahan nilai CBR yang paling maksimum. Contoh pada data 4, nilai CBR akan terus naik dari penambahan $25 \%$, 50\%, hingga $75 \%$ slag, nilai CBR yang didapat $35 \%$ meningkat menjadi $60 \%$, $80 \%$ lalu menurun saat 
pertambahan slag sebanyak 100\%, maka nilai CBR yang didapat akan turun menjadi 70\%. Pertambahan slag paling maksimum berada pada penambahan slag sebesar 75\%, lebih atau kurang dari 75\% slag hasil penambahan nilai CBR nya menurun.

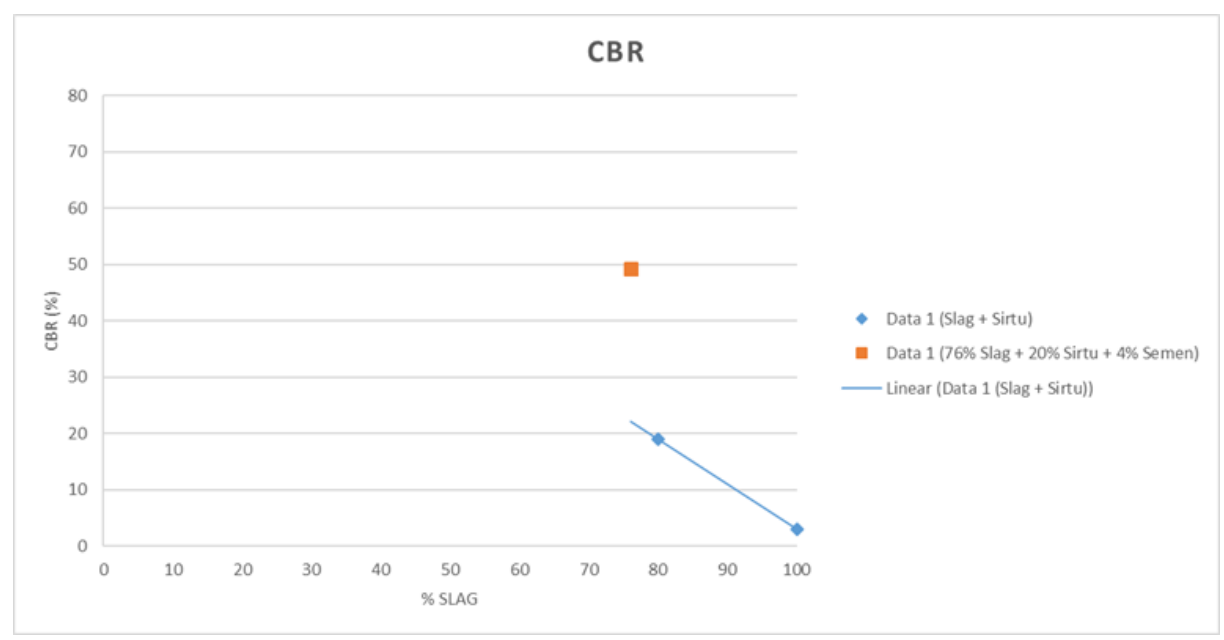

Gambar 10. Grafik nilai CBR pada pasir batu dengan slag

Pada pencampuran $20 \%$ pasir batu dengan steel slag sebesar $80 \%$ nilai CBR yang didapat adalah 19,021\%. Kadar pencampuran steel slag dengan pasir batu yang paling optimum adalah dengan presentase campuran $76 \%$ steel slag dengan $4 \%$ semen lalu dicampurkan dengan $20 \%$ pasir batu dengan nilai CBR yang didapat adalah sebesar 49,251\%. Dan pada saat dilakukan pengetesan dengan steel slag $100 \%$ nilai CBR yang didapat menurun hingga $2,95 \%$

\section{Grafik pengaruh penambahan slag terhadap berat jenis tanah (Gs)}

Pada data 1, nilai Gs pada $100 \%$ slag berkisar antara $3-3,05$. Pada data 2, pencampuran slag mulai dari $0 \%$ sampai dengan $20 \%$ nilai Gs didapat 2,6 - 2,796. Untuk data 3, 4 dan 6, nilai Gs pada 100\% slag adalah 3,1, 2,75, 2,312. Pada data 5, pencampuran slag dari $0 \%$ - 25\% nilai Gs didapat 2,56-2,63. Dan terakhir pada data 6, penambahan nilai Gs dari 2,53 (saat tanah asli) menjadi 2,55 (saat dicampurkan dengan 13\% slag). Dapat dilihat pada gambar 11 .

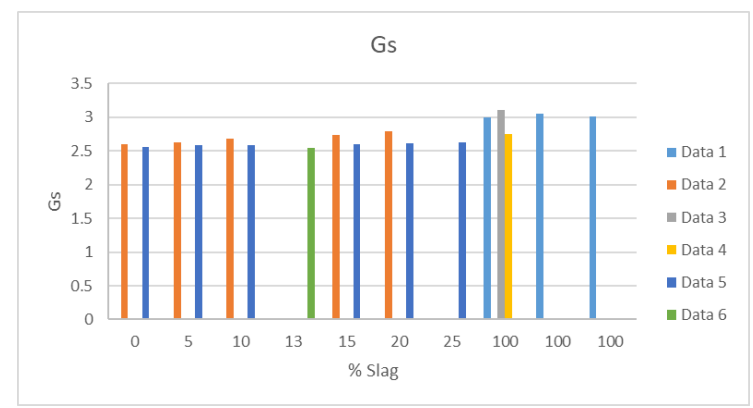

Gambar 11. Perbandingan data berat jenis tanah

\section{Grafik pengaruh penambahan slag terhadap nilai berat isi kering maksimum ( $\gamma$ dry maks)}

Pada data 2 (gambar 12) saat tanah belum tercampur slag nilai berat isi kering maksimum adalah $1,368 \mathrm{gr} / \mathrm{cm}^{3}$, lalu persentase slag sebesar 5\%,10\%, 15\% dan 20\% mengalami kenaikan menjadi 1,383 gr/cm ${ }^{3}, 1,403 \mathrm{gr} / \mathrm{cm}^{3}$, $1,415 \mathrm{gr} / \mathrm{cm}^{3}$ dan $1,411 \mathrm{gr} / \mathrm{cm} 3$. Nilai besarnya berat isi kering maksimum tanah pada data 4 (gambar 13) adalah pada saat sampel tanah asli adalah sebesar $1,9 \mathrm{gr} / \mathrm{cm}^{3}$, pada persentase slag sebesar $25 \%, 50 \%$ dan $75 \%$ mengalami kenaikan sebesar $2,08 \mathrm{gr} / \mathrm{cm}^{3}, 2,25 \mathrm{gr} / \mathrm{cm}^{3}$ dan $2,38 \mathrm{gr} / \mathrm{cm}^{3}$. 


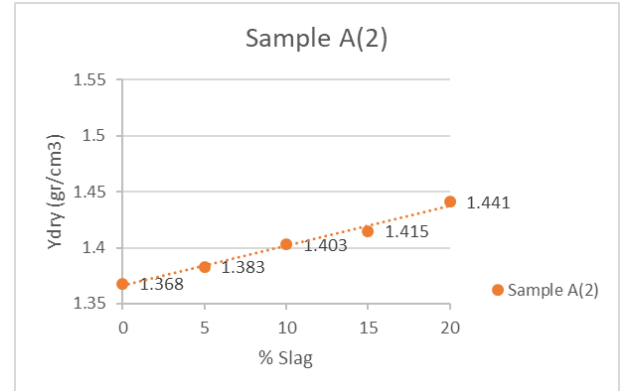

Gambar 12. Grafik berat isi kering maksimum sampel A data 2 (Sumber: Ardiyanti dan Andajani, 2014)

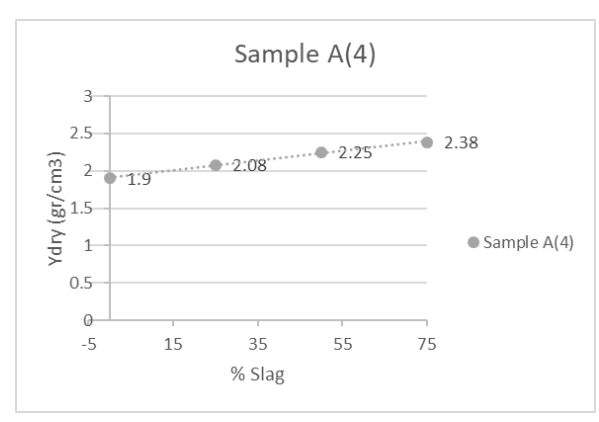

Gambar 13. Grafik berat isi kering maksimum sampel A data 4 (Sumber: Sinha, dkk, 2013)

Kenaikan berat isi kering maksimum pada data 5 (gambar 14) adalah dari $1,71 \mathrm{gr} / \mathrm{cm}^{3}, 1,726 \mathrm{gr} / \mathrm{cm}^{3}, 1,735 \mathrm{gr} / \mathrm{cm}^{3}$, $1,75 \mathrm{gr} / \mathrm{cm}^{3}$ dan $1,756 \mathrm{gr} / \mathrm{cm}^{3}$. Dari Persentase slag 0\%, 5\%, 10\%, 15\%, dan 20\%. Pada data 6 (gambar 15), nilai berat isi kering maksimum pada tanah dicampurkan dengan slag sebesar 0\%, 10\%, 13\%, 15\%, 18\% sampai dengan $20 \%$ nilai berat isi kering maksimum yang didapat sebesar $1,54 \mathrm{gr} / \mathrm{cm}^{3}, 1,671 \mathrm{gr} / \mathrm{cm}^{3}, 1,69 \mathrm{gr} / \mathrm{cm}^{3}, 1,67$ $\mathrm{gr} / \mathrm{cm}^{3}, 1,64 \mathrm{gr} / \mathrm{cm}^{3}, 1,62 \mathrm{gr} / \mathrm{cm}^{3}$.

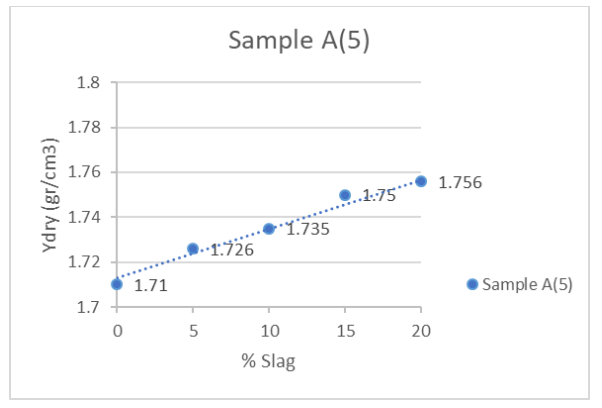

Gambar 14. Grafik berat isi kering maksimum sampel A data 5 (Sumber: Pathak, dkk, 2014)

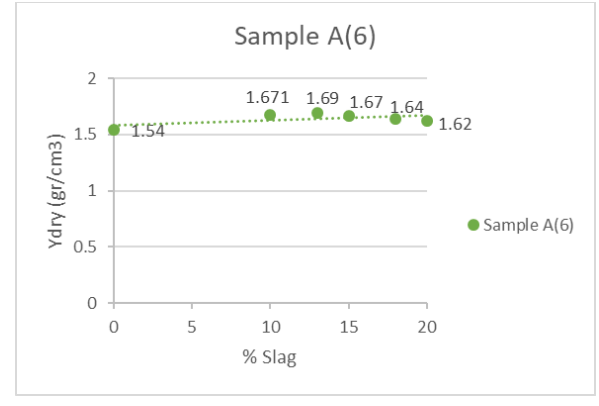

Gambar 15. Grafik berat isi kering maksimum sampel A data 6 (Sumber: D. Koteswara Rao, dkk, 2014)

Nilai berat isi kering maksimum pada tanah data 7 (gambar 16) adalah sebesar $1,4 \mathrm{gr} / \mathrm{cm}^{3}$, penambahan slag sebesar 5\%, 10\%, 15\% nilai berat isi kering maksimum yang didapat sebesar 1,45 gr/ $/ \mathrm{cm}^{3}, 1,53 \mathrm{gr} / \mathrm{cm}^{3}, 1,48$ $\mathrm{gr} / \mathrm{cm}^{3}$. Maka, pertambahan nilai berat isi kering maksimum tertinggi pada saat persentase slag yang digunakan pada data 8 (gambar 17) adalah sebesar 10\%. Pada data 8, berat isi kering maksimum sampel tanah asli yang digunakan adalah sebesar $1,007 \mathrm{gr} / \mathrm{cm}^{3}$, penambahan slag sebesar $5 \%$ dan $10 \%$ kenaikan berat isi kering maksimum adalah sebesar $1,062 \mathrm{gr} / \mathrm{cm}^{3}$, dan $1,049 \mathrm{gr} / \mathrm{cm}^{3}$.

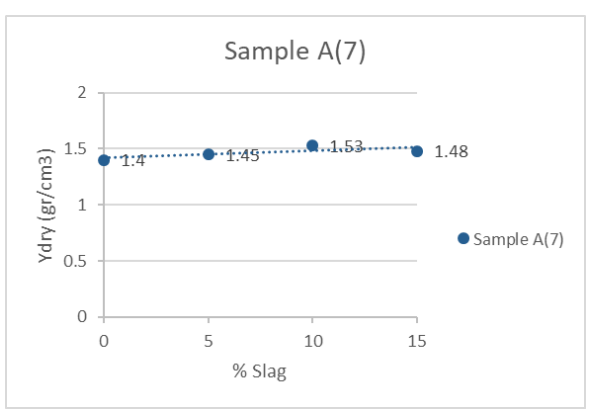

Gambar 16. Grafik berat isi kering maksimum sampel A data 7 (Sumber: Zumrawi and Babikir, 2017)

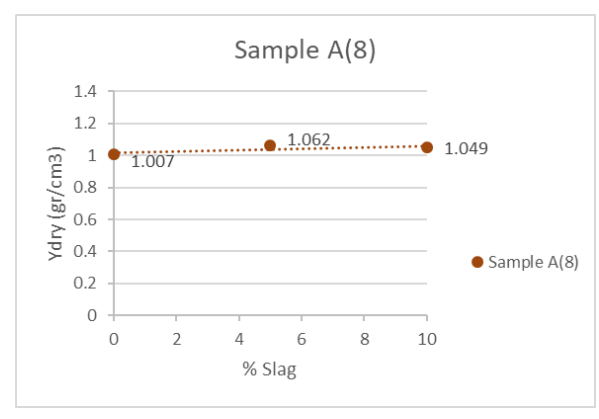

Gambar 17. Grafik berat isi kering maksimum sampel A data 8 (Sumber: Kurnaedi, 2019)

Untuk data 9 (gambar 18), nilai berat isi kering maksimum yang diuji dimulai dari pencampuran 5\% slag dengan tanah didapat besarnya $1,57 \mathrm{gr} / \mathrm{cm}^{3}$, lalu dilanjutkan penambahan $10 \%, 15 \%, 20 \%$ hingga $25 \%$ slag nilai berat isi kering maksimum yang didapat $1,62 \mathrm{gr} / \mathrm{cm}^{3}, 1,65 \mathrm{gr} / \mathrm{cm}^{3}, 1,7 \mathrm{gr} / \mathrm{cm}^{3}, 1,68 \mathrm{gr} / \mathrm{cm}^{3}$. Maka pertambahan nilai berat isi kering maksimum tertinggi pada saat persentase slag yang digunakan pada data 9 adalah sebesar 20\%. Nilai berat isi kering maksimum sampel tanah asli yang digunakan pada data 10 (gambar 19) adalah sebesar 1,804 
Studi Literatur Pencampuran Material Tanah Lempung dan

$\mathrm{gr} / \mathrm{cm}^{3}$, penambahan slag sebesar 10\%, 20\%, 30\%, 40\%, hingga 50\% kenaikan berat isi kering maksimum yang didapat adalah sebesar $1,838 \mathrm{gr} / \mathrm{cm}^{3}, 1,868 \mathrm{gr} / \mathrm{cm}^{3}, 1,91 \mathrm{gr} / \mathrm{cm}^{3}, 1,97 \mathrm{gr} / \mathrm{cm}^{3}, 1,975 \mathrm{gr} / \mathrm{cm}^{3}$.

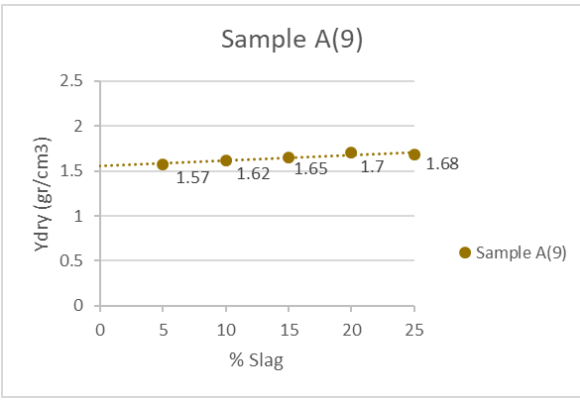

Gambar 18. Grafik berat isi kering maksimum sampel A data 9 (Sumber: Palve and Sharma, 2018)

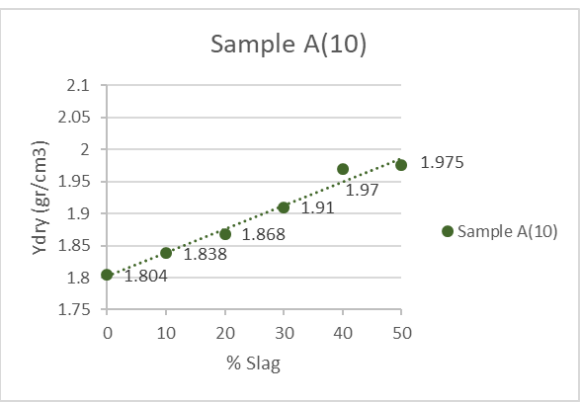

Gambar 19. Grafik berat isi kering maksimum sampel

A data 10 (Sumber: Biradar, dkk, 2014)

\section{Grafik pengaruh penambahan slag terhadap kadar air optimum (wopt)}

Pada data 2 (gambar 20), sampel kadar air optimum pada sampel tanah asli adalah sebesar 28,3\%, penambahan slag sebesar 5\%, 10\%, 15\%, hingga 20\% kadar air yang didapat adalah 27,5\%, 26,5\%, 25\% dan $24 \%$. Pada data 4 (gambar 21), sampel kadar air optimum pada sampel tanah asli adalah sebesar 12\%, pada pencampuran tanah dengan 25\% slag tidak memiliki pengaruh terhadap penurunan kadar air. Lalu ketika kadar slag dinaikkan sebesar $50 \%$ terlihat penurunan kadar air sehingga mencapai $9 \%$ dan tetap hingga kadar slag sebesar $75 \%$. Pertambahan slag dapat menurunkan kadar air optimum pada tanah.

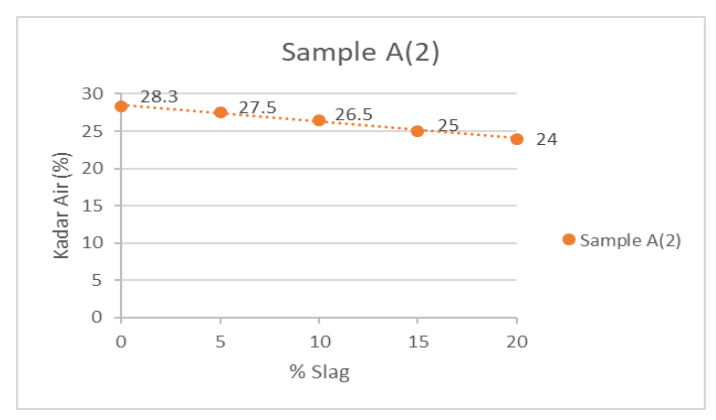

Gambar 20. Grafik wopt sampel A data 2 (Sumber: Ardiyanti dan Andajani, 2014)

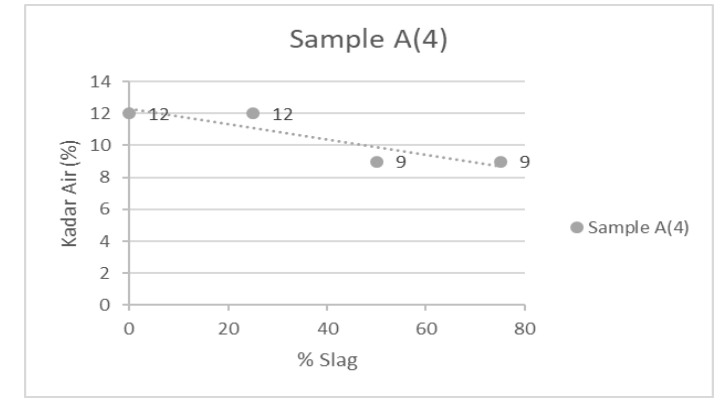

Gambar 21. Grafik wopt sampel A data 4 (Sumber: Sinha, dkk, 2013)

Besar kadar air optimum pada tanah data 5 (gambar 22) adalah 14,33\%, lalu kadar air akan terus menurun pada persentase 5\%, 10\%, 15\% sampai sebesar 20\%, nilainya adalah 14,13\%, 13,54\%, 13,15\%, dan 12,75\%. Pada data 6 (gambar 23), sampel kadar air optimum pada sampel tanah asli adalah sebesar 27,4\%, pada pencampuran tanah dengan $10 \%, 13 \%, 15 \%, 18 \%$, dan $20 \%$ slag akan mengurangi besar kadar air optimum pada tanah yaitu sebesar $27,2 \%, 19,35 \%, 26,31 \%, 23,93 \%$ dan $23,53 \%$.

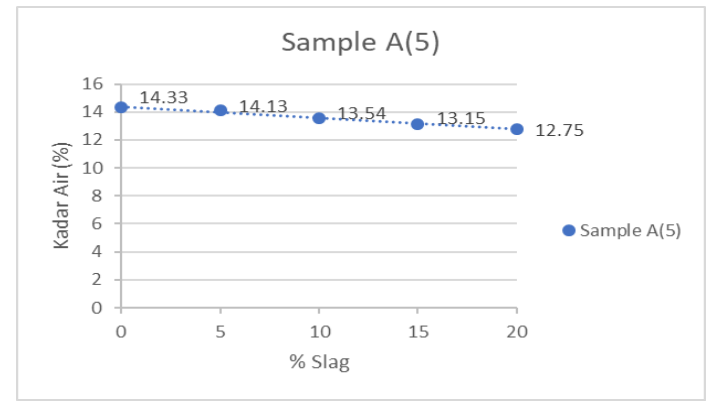

Gambar 22. Grafik wopt sampel A data 5 (Sumber: Pathak, dkk, 2014)

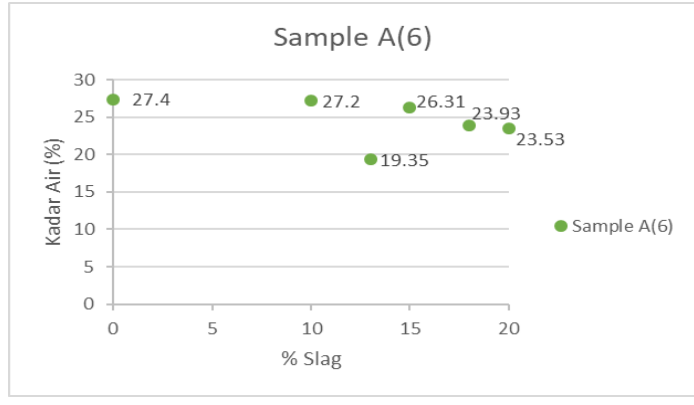

Gambar 23. Grafik wopt sampel A data 6 (Sumber: D. Koteswara Rao, dkk, 2014) 
Pada data 7 (gambar 24), didapat data kadar air optimum pada tanah adalah sebesar 27,5\%, lalu pada saat persentase kadar slag ditambahkan menjadi 5\%, 10\%, dan 15\% maka kadar air turun menjadi 22,5\%, 22,4\%, dan $20,6 \%$. Besar kadar air optimum tanah pada data 8 (gambar 25) adalah 57,2\% pencampuran tanah dengan sebesar $5 \% 10 \%$ maka kadar air optimum yang didapatkan menurun hingga 47,46\%, dan 48,14\%.

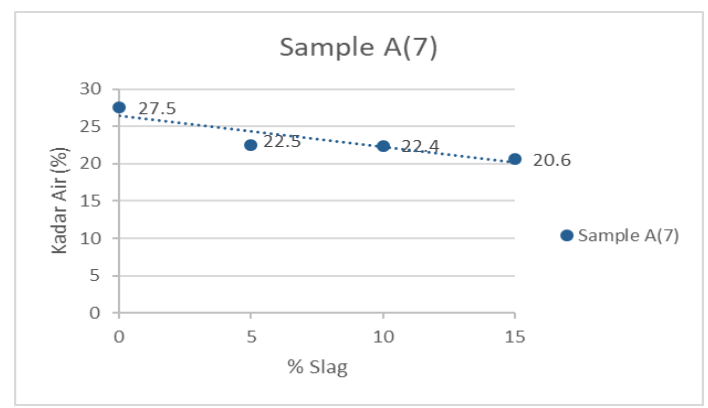

Gambar 24. Grafik wopt sampel A data 7 (Sumber: Zumrawi and Babikir, 2017)

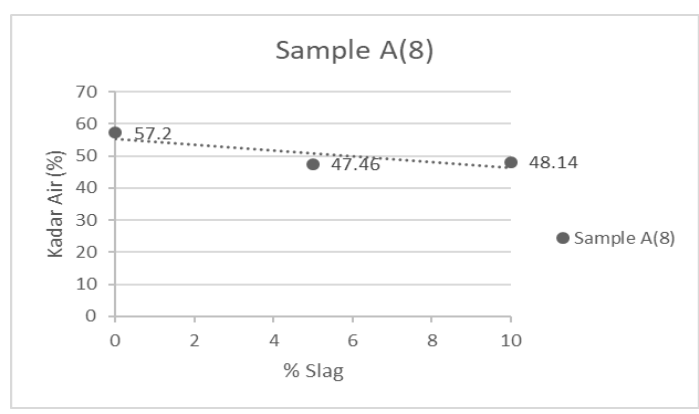

Gambar 25. Grafik wopt sampel A data 8 (Sumber: Kurnaedi, 2019)

Pada data 9 (gambar 26) pencampuran tanah dengan slag dimulai dari 5\% penambahan bahan slag dengan nilai yang didapat adalah 23\%, lalu akan turun ketika ditambahkan 10\%, 15\%, 20\%, dan 25\% slag sehingga nilainya menjadi 23\%, 21,5\%, dan 20,5\% dan 17,5\%. Nilai kadar air optimum tanah pada data 10 (gambar 27) adalah 15,8\%. Pencampuran tanah dengan slag dimulai dari 10\%, 20\%, 30\%, 40\% dan 50\% penambahan bahan slag dengan nilai kadar air optimum yang didapat adalah 14,2\%, 12,9\%, 11,4\%, 10,5\% dan 9,6\%

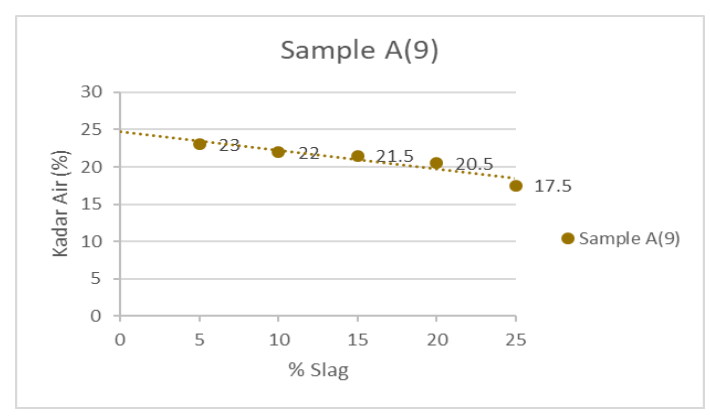

Gambar 26. Grafik wopt sampel A data 9 (Sumber: Palve and Sharma, 2018)

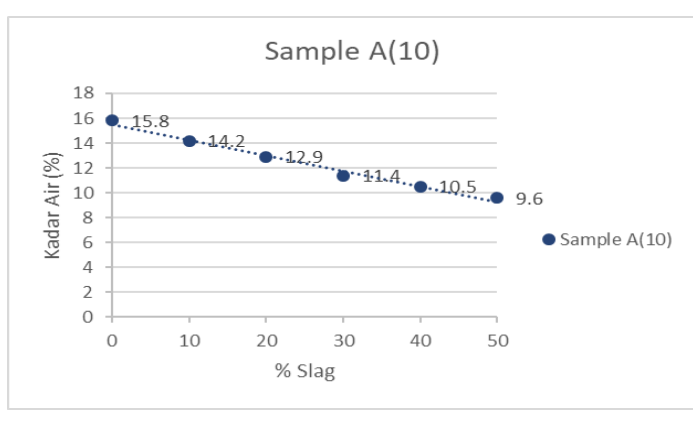

Gambar 27. Grafik wopt sampel A data 10 (Sumber: Biradar, dkk, 2014)

\section{Grafik pengaruh penambahan slag terhadap kembang susut tanah (swelling)}

Pada data 3 (gambar 28) tanah mengalami penurunan kembang susut dari 5.44\% pada tanah asli dan akan terus menurun menjadi 4,66\%, 3,88\%,3,1\%, 2,32\%, 1,54\%, hingga $0,76 \%$ saat slag $5 \%, 10 \%, 15 \%, 20 \%$, 25\% hingga $30 \%$. Pada data 7 (gambar 29) tanah mengalami penurunan kembang susut mulai dari $2.88 \%$ pada saat tanah asli, saat penambahan slag sebesar 5\%, 10\%, 20\%, dan 25\% nilai swell menjadi 2,7\%, 2,2\%, dan 1,3\%.

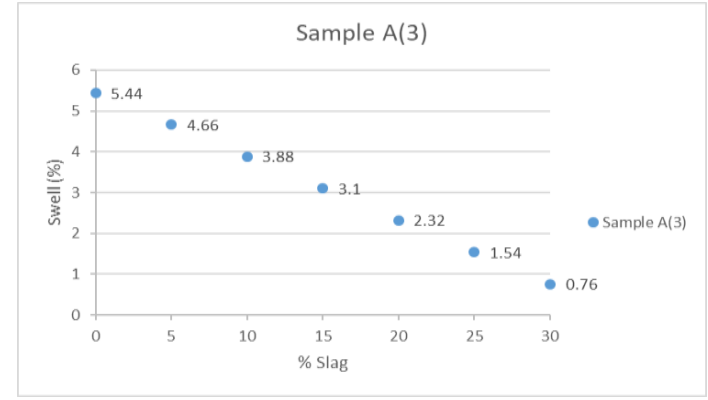

Gambar 28. Grafik swelling sampel A data 3 (Sumber: Shalabi, dkk, 2016)

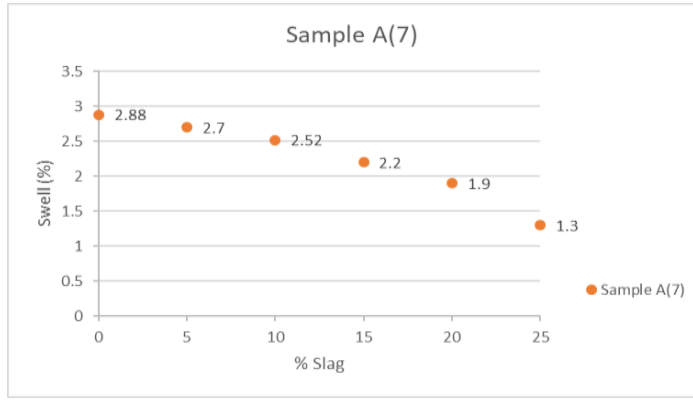

Gambar 29. Grafik swelling sampel A data 7 (Sumber: Zumrawi and Babikir, 2017) 
Pada data 8 (gambar 30) tanah mengalami penurunan kembang susut mulai dari $0,305 \%$ pada saat tanah asli, saat $5 \%$ menurun hingga $0,167 \%$, dan saat $10 \%$ menurun hingga $0,217 \%$.

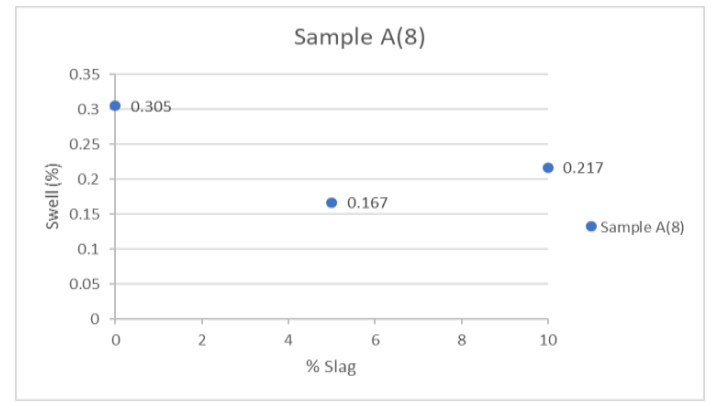

Gambar 30. Grafik swelling sampel A data 8 (Sumber: Kurnaedi, 2019)

\section{Grafik pengaruh penambahan slag terhadap index plastisitas tanah (IP)}

Nilai indeks plastis tanah pada data 2 (gambar 31) adalah 54,4\%. Ketika dilakukan penambahan slag sebesar 5\%, $10 \%, 15 \%$, dan $20 \%$ maka besar IP tanah menurun menjadi 45,9\%, 42,71\%, 37,85\% dan menurun sampai dengan $33,81 \%$. Nilai indeks plastis tanah pada data 3 (gambar 32) adalah 23,64\%. Pada saat dilakukan penambahan slag sebesar 5\%, 10\%, 15\%, 20\% dapat menyebabkan besar IP tanah menurun menjadi 21,79\%, 19,93\%, 18,07\%, $16,22 \%$, dan $12,5 \%$.

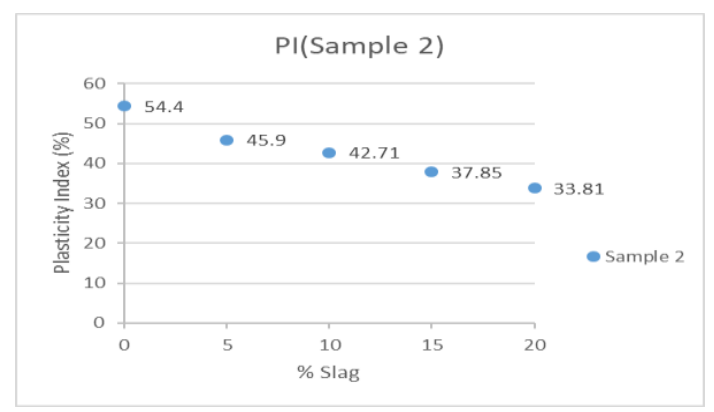

Gambar 31. Grafik index plastisitas sampel A data 2 (Sumber: Ardiyanti dan Andajani, 2014)

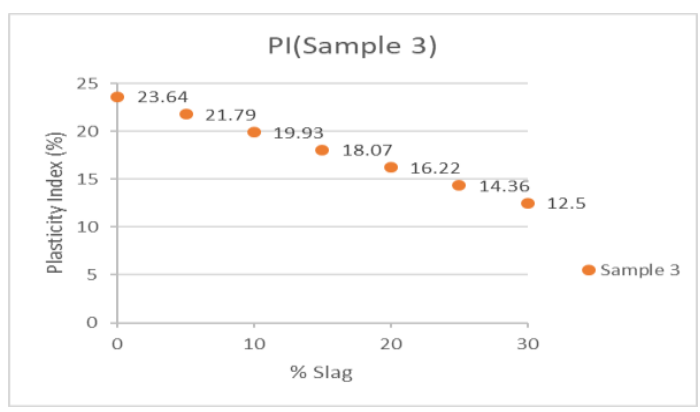

Gambar 32. Grafik index plastisitas sampel A data 3 (Sumber: Shalabi, dkk, 2016)

Pada data 6 (gambar 33), pertambahan slag juga mempengaruhi pengurangan nilai plastisitas. Nilai IP tanah asli adalah 37,78\% lalu pada saat pencampuran tanah dengan slag sebesar $13 \%$ nilai IP menurun menjadi $35,74 \%$. Besar nilai IP pada tanah data 7 (gambar 34) adalah 36\%, pencampuran slag sebesar 5\%, 15\%, 20\%, 25\% hingga $30 \%$ menjadi $30 \%, 25 \%, 19 \%, 16 \%$ dan $9 \%$.

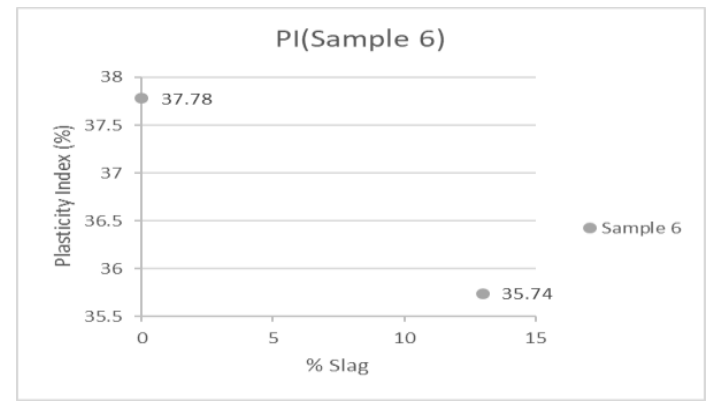

Gambar 33. Grafik index plastisitas sampel A data 6 (Sumber: D. Koteswara Rao, dkk, 2014)

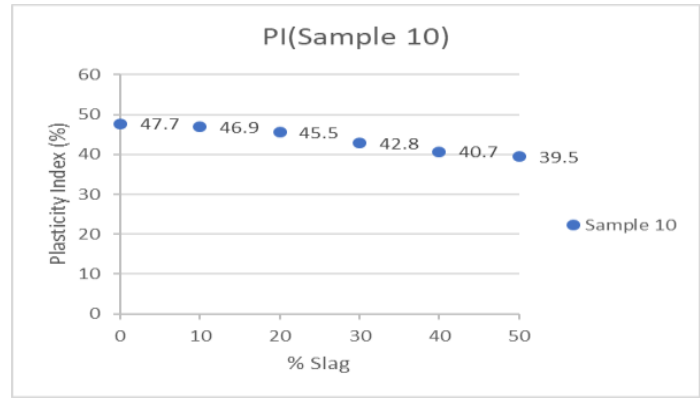

Gambar 34. Grafik index plastisitas sampel A data 7 (Sumber: Zumrawi and Babikir, 2017)

Nilai indeks plastis tanah pada data 10 (gambar 35) adalah 47,7\%. Saat dilakukan penambahan slag sebesar 10\%, $20 \%, 30 \%, 40 \%$ dan 50\% maka besar IP tanah menurun menjadi 46,9\%, 45,5\%, 42,8\%, 40,7\% dan 39,5\%. 


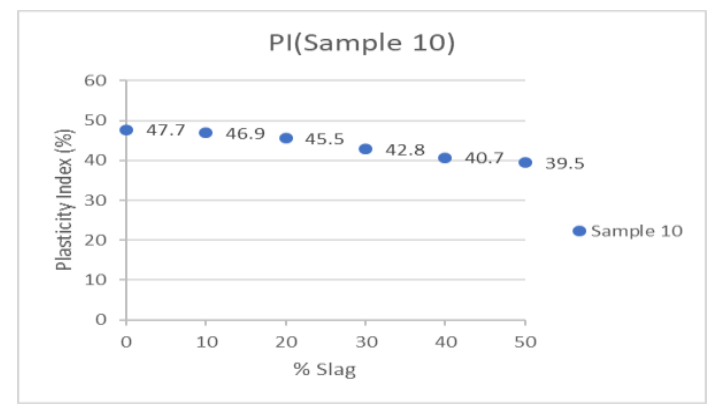

Gambar 35. Grafik index plastisitas sampel A data 10 (Sumber: Biradar, dkk, 2014)

\section{Grafik pengaruh penambahan slag terhadap batas cair tanah (LL)}

Sampel tanah asli pada data 2 (gambar 36) batas cair sebesar 79,76\%. Penambahan slag 5\%, 10\%, 15\%, dan 20\% berkurang menjadi $71,96 \%, 69,79 \%, 68,74 \%$, dan $67,55 \%$. Sampel tanah asli pada data 3 (gambar 37) memiliki nilai batas cair sebesar 51,17\%. Nilai batas cair pada campuran sampel tanah dengan slag sebesar $5 \%, 10 \%$, 15\%, $20 \%, 25 \%$ dan $30 \%$ berkurang menjadi $48 \%, 44,83 \%, 41,67 \%, 38,5 \%, 35,33 \%, 32,17 \%$.

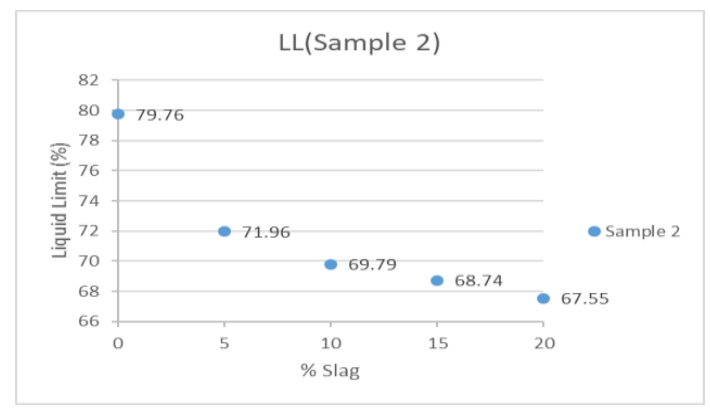

Gambar 36. Grafik batas cair sampel A data 2 (Sumber: Ardiyanti dan Andajani, 2014)

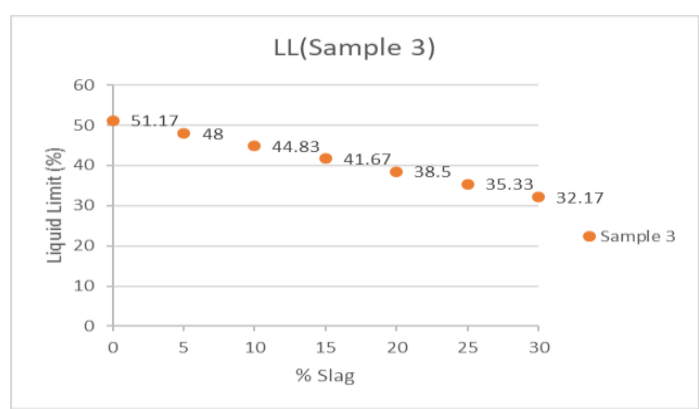

Gambar 37. Grafik batas cair sampel A data 3 (Sumber: Shalabi, dkk, 2016)

Sampel tanah asli pada data 6 (gambar 38) memiliki nilai batas cair sebesar 70,7\%. Lalu pada saat penambahan $13 \%$ slag nilai batas cair menurun menjadi 57,75\%. Sampel tanah asli pada data 7 (gambar 39) memiliki batas cair sebesar $66 \%$. Nilai batas cair pada campuran sampel tanah dengan pasir sebesar 5\%, 15\%, 20\%, 25\% dan 30\% berkurang menjadi $61 \%, 58 \%, 54 \%, 50 \%$, hingga $44 \%$.

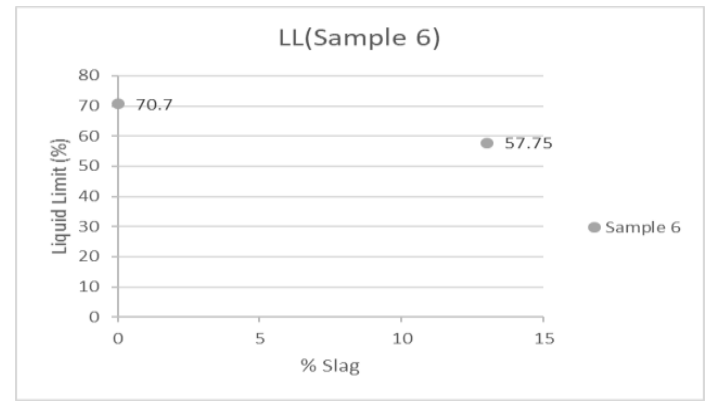

Gambar 38. Grafik batas cair sampel A data 6 (Sumber: D. Koteswara Rao, dkk, 2014)

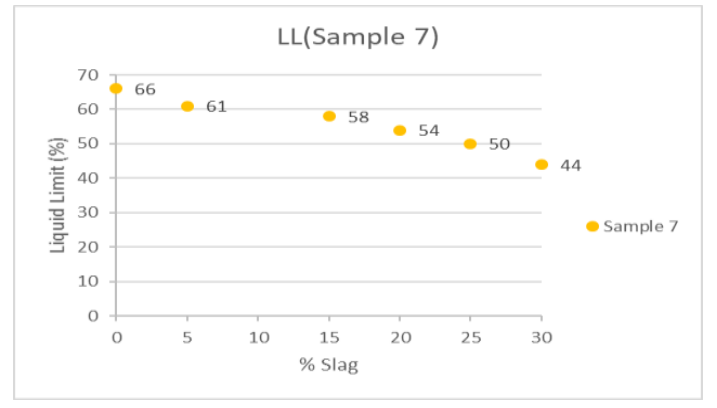

Gambar 39. Grafik batas cair sampel A data 7 (Sumber: Zumrawi and Babikir, 2017)

Sampel tanah asli pada data 10 (gambar 40) memiliki batas cair sebesar 47.7\%. Nilai batas cair pada campuran sampel tanah dengan pasir sebesar 10\%, 20\%, 30\%, 40\% dan 50\% berkurang menjadi 45,8\%, 43,3\%, 40,7\%, $38,9 \%$ hingga $36,75 \%$. 


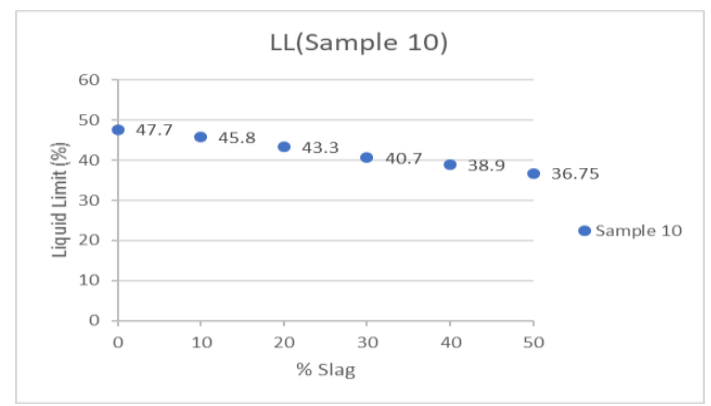

Gambar 40. Grafik batas bair sampel A data 10 (Sumber: Biradar, dkk, 2014)

\section{Grafik pengaruh penambahan slag terhadap batas plastis tanah (PL)}

Nilai batas plastis pada data 2 (gambar 41) mengalami kenaikan, dimulai dari nilai batas plastis pada sampel tanah asli adalah sebesar 25,36\%, dengan penambahan sebesar 5\% slag didapat nilai PL sebesar 26,06\%, lalu ditambahkan dengan $10 \%$ slag nilai PL nya adalah sebesar $27,07 \%$, dan pada saat penambahan sebesar $15 \%$ dan $20 \%$ nilai batas plastis akan terus bertambah menjadi 30,88\% sampai dengan 33,74\%. Pertambahan nilai batas plastis tanah sedikit. Nilai batas plastis pada data 6 (gambar 42) mengalami pengurangan, nilai batas plastis pada sampel tanah asli adalah sebesar 25,36\%, lalu ketika dicampur dengan $13 \%$ slag nilai batas plastis berkurang menjadi $22,01 \%$.

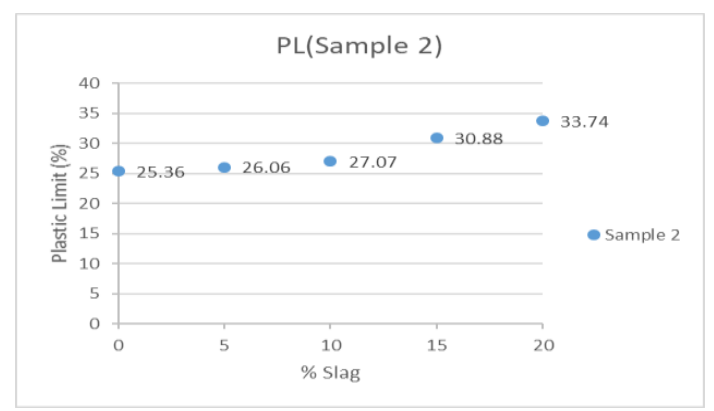

Gambar 41. Grafik batas plastis sampel A data 2 (Sumber: Ardiyanti dan Andajani, 2014)

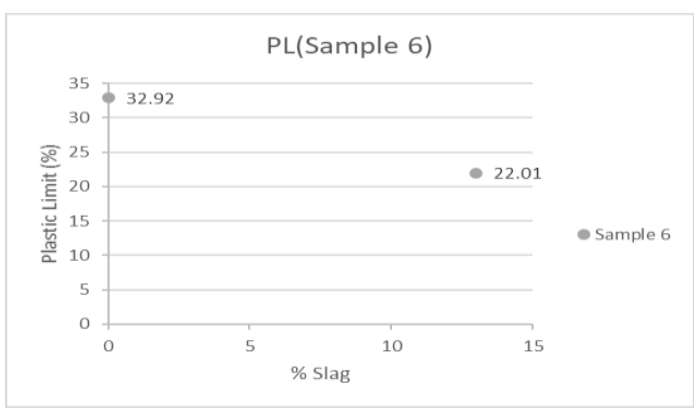

Gambar 42. Grafik batas plastis sampel A data 6 (Sumber: D. Koteswara Rao, dkk, 2014)

Nilai batas plastis pada data 7 (gambar 43) mengalami penambahan, dimulai dari nilai batas plastis pada sampel tanah asli adalah sebesar 30\%, lalu ketika dicampur dengan 5\% slag nilai batas plastis meningkat hingga 31\%, dan terus meningkat hingga persentase pencampuran sebesar 15\%, 20\%, 25\%, dan 30\% yaitu bertambah sebesar 33\%, $35 \%, 34 \%$, sampai dengan 35\%. Pertambahan nilai batas plastis pada tanah relatif sedikit.

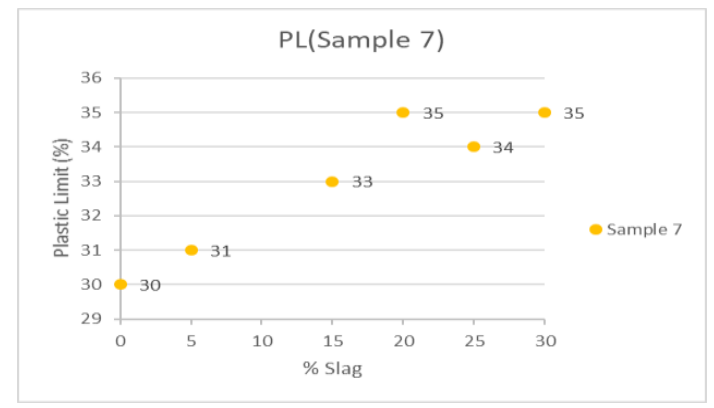

Gambar 43. Grafik batas plastis sampel A data 7 (Sumber: Zumrawi and Babikir, 2017)

\section{KESIMPULAN DAN SARAN}

\section{Kesimpulan}

Kesimpulan dalam penelitian ini adalah:

1. Penambahan slag pada tanah asli akan mengakibatkan naiknya nilai CBR tanah. Pertambahan nilai CBR yang paling maksimum, terdapat pada kadar slag tertentu. 
2. Penambahan material semen dalam pencampuran slag dengan sirtu dapat mempengaruhi kenaikan nilai CBR. Berdasarkan nilainya. ( $4 \%$ semen $+76 \%$ slag $+20 \%$ sirtu; $C B R=49,251 \%$ )

3. Kenaikan kepadatan tanah diakibatkan karena proses dimana air dan udara atau pori-pori tanah semakin kecil. Jadi semakin berkurangnya angka pori, maka mengakibatkan berat butiran semakin besar sedangkan volume total tanah basah menjadi semakin berkurang.

4. Penambahan slag dengan tanah mengakibatkan kadar air menurun dan berat jenis kering meningkat, dikarenakan kompaktibilitas tanah meningkat dan membuat tanah lebih keras dan padat.

5. Slag dapat mengurangi nilai kembang susut pada tanah, karena sifat limbah baja yang tidak mengembang dan menyusut.

6. Penurunan pada plastisitas tanah (IP) dan batas cair pada tanah, disebabkan karena adanya penambahan slag yang dicampurkan pada tanah sehingga menyebabkan batas cair dan plastisitas tanah menjadi berkurang diakibatkan karena sifat non-plastic dari steel slag.

\section{Saran}

Saran untuk melengkapi penelitian ini adalah:

1. Perlu melakukan penelitian mengenai kadar kimia pada slag, karena kadar kimia yang terkandung didalam steel slag bisa berbeda.

2. Untuk melengkapi penelitian ini, perlu adanya pengujian direct shear pada sampel slag untuk mengetahui nilai kuat geser pada steel slag.

\section{DAFTAR PUSTAKA}

Ardiyanti, Tika and Nur Andajani. "Pengaruh Penambahan Limbah Baja (Slag) Pada Tanah Lempung di Daerah Babat Lamongan." Rekayasa Teknik Sipil Vol 3 Nomer 3/rekat/14 (2014): 158-165.

American Society for Testing and Material. ASTM D 854-83. Test method for specific gravity of soils.

American Society for Testing and Material. ASTM D 422-63. Test method for particle size analysis of soils.

American Society for Testing and Material. ASTM D 1140-54. Test method for amount of material in soils finer than the no. $200(75 \mu \mathrm{m})$.

American Society for Testing and Material. ASTM D 4318-00. Standard Test Method for Liquid Limit, Plastic. Limit, and Plasticity Index of Soils.

American Society for Testing and Material. ASTM D 2216. Standard Test Method for Laboratory Determination of Water (Moisture) Content of Soil and Rock by Mass.

Badan Standardisasi Nasional. SNI 8378:2017. Spesifikasi lapis fondasi dan lapis fondasi bawah menggunakan slag.

Badan Standardisasi Nasional. SNI 8379:2017. Spesifikasi Material Pilihan (selected material) Menggunakan Slag Untuk Kontruksi Jalan

Biradar, Kiran B., U. Arun Kumar and Dr.PVV Satyanarayana. "Influence of Steel Slag and Fly Ash on Strength Properties of Clayey Soil: A Comparative Study." ResearchGate (2014): Volume 14 Number 2.

Kurnaedi, William. "Studi Laboratorium Variasi Campuran Slag Baja dan Slag Feronikel Terhadap Penurunan Kadar Air, Peningkatan Nilai CBR, dan Kuat Tekan Tanah, Studi Kasus Jalan Tol Bocimi STA. 19+125, Bogor." Bandung: Universitas Katolik Parahyangan, 2019.

Laboratorium Pengetesan Slag. "Laporan Pengujian Laboratorium Electric Furnace Cilegon, Banten." 2017.

Palve, Miss Sangita Z and Dr. V. K. Sharma. "Investigation on Percentage Addition of Sand, Red murrum and Steel slag for Strengthening the Subgrade Soil." International Advanced Research Journal in Science, Engineering and Technology (2018): Vol. 5, Issue 5.

Pathak, Ashish Kumar, et al. "Soil Stabilisation Using Ground Granulated Blast Furnace Slag." Journal of Engineering Research and Applications (2014): 164-171.

Rao, D. Koteswapeckra, G. Sravani and Naga Bharath. "A Laboratory Study on the Affect of Steel Slag for Improving the Properties of Marine Clay for Foundation Beds." India, 2014.

Shalabi, Faisal I., Ibrahim M. Asi and Hisham Y. Qasrawi. "Effect of By-Product Steel Slag on the Engineering Properties of Clay Soils." Journal of King Saud University - Engineering Sciences (2016): 6.

Sinha, Anil, Sudhir Mathur and Vasant G Havanagi. "Steel Slag Waste Material for the construction of Road." ResearchGate (2013).

Zumrawi, Magdi Mohamed Eltayeb and Alaa Abdel-Aziz Ali Babikir. "Laboratory Study of Steel Slag Used in Stabilizing Expansive Soil." Asian Engineering Review (2017): Vol. 4, No. 1-6. 
